\title{
Fortrolige modstandere: Vietnam og Kina
}

Af Flemming Ytzen

Koldkrigsæraens ideologiske antiimperialisme vendt mod USA har måttet vige for klassiske interessesammenstød i relationerne mellem de to asiatiske udviklingsstater, der er fælles om at udvikle 'markedsleninismen'.

Den amerikanske politiker John McCain (født 1936), der var krigsfange i den nordvietnamesiske hovedstad Hanoi 1967-1973, skal engang have udtalt, at hvis præsidentvalget i 1964 havde fået den republikanske kandidat Barry Goldwater som vinder, ville USA's militære engagement i Sydvietnam have udviklet sig til en krig mod ikke bare det kommunistiske Nordvietnam, men også dette lands hovedallierede, Folkerepublikken Kina.

Nu blev det Lyndon B. Johnson fra Demokraterne, der vandt i 1964 og efterfølgende udvidede krigsførelsen i Vietnam dramatisk og massivt. Da Johnson i 1968 overraskende meddelte, at han ikke genopstillede, blev banen åbnet for republikaneren Richard
Nixon, som ikke bare lovede 'fred med ære' i Vietnam, men også en amerikansk kursændring i forhold til det Kina, som havde været i konfrontation med USA siden den kinesiske intervention i Koreakrigen i 1950, hvor amerikanske og kinesiske styrker udkæmpede en regulær stedfortræderkrig.

Krigshandlingerne i Vietnam havde mange modsætningsfyldte aspekter, men rummede en vis logik i det større koldkrigsperspektiv: med USA og Sovjetunionen i ideologisk og militær konfrontation ikke kun i et jerntæppedelt Europa, men også på de såkaldte tredjeverdens-kontinenter, Asien, Latinamerika og Afrika.

Mens Moskva og Beijing leverede penge og våben til Hanoi, stod USA næsten alene med opbakningen til Sydvietnam. Mens både Frankrig og Storbritannien afviste amerikanske opfordringer til at deltage i krigen, var der i kortere perioder canadiske, australske, thailandske, filippinske og sydkoreanske soldater i Sydvietnam som et resultat af Lyndon Johnsons 'more flags'-kampagne. 
Amerikansk støtte til Beijings arvefjende, det nationalistkinesiske styre på Taiwan, blev af Kina med rette set som en amerikansk inddæmning af Kina; det samme gjorde den amerikanske beskyttelse af Sydvietnam og Sydkorea.

\section{Richard Nixon ændrede alt}

Alt dette skulle Nixon, der var en forhærdet antikommunist fra tiden som vicepræsident under præsident Dwight D. Eisenhower 1953-1960, ændre på.

I oktober 1967 skrev han i tidsskriftet Foreign Affairs (i en artikel med overskriften 'Asia After Vietnam'), at verden aldrig kunne blive et sikkert sted, så længe Kina blev forblev isoleret. Her følger et centralt afsnit af artiklen:

"På det lange sigt har vi ganske enkelt ikke råd til i al evighed at holde Kina uden for nationernes familie. For det er $\mathrm{i}$ isolation, at Kina hadefuldt truer sine naboer. Der bør på denne planet ikke være plads til, at en milliard af klodens potentielt mest kapable individer lever $\mathrm{i}$ vred afsondrethed (...) Verden bliver ikke sikker, før Kina forandrer sig. Vores politik må handle om at fremme denne forandring. Vi må overbevise Kina om, at det ikke kan få opfyldt sine imperiale ambitioner. Det må se indad for at bruge kræfterne på at løse sine egne problemer."

Læser man citatet med nutidige briller, altså med fem årtiers forskydning, er det indlysende at nå til den foreløbige konklusion, at Kinas reformpolitik har bragt Østasiens største og ældste statsdannelse meget langt $\mathrm{i}$ håndteringen af interne ud- fordringer. Men en anden konklusion vil lyde, at Kinas 'imperiale ambitioner' er ved at træde i karakter, først og fremmest i Det Sydkinesiske Hav.

Intet sted i Sydøstasien er der større ængstelighed over Kinas magtambitioner end i Vietnam.

Historisk er der næppe noget folkeslag, der kender kinesisk kulturel og politisk adfærd bedre end netop vietnameserne, hvis nordlige del i mange århundreder var underlagt forskellige former for kinesisk dominans og påvirkning. Skiftende vietnamesiske dynastier blev præget og formet af den kungfutsianske embedsmandslære, som har domineret Kina hen over ca. 2.500 år.

I officiel vietnamesisk historieskrivning opnår den nordlige del af landet uafhængighed fra Kina i år 939 e.Kr., men heller ikke i de følgende århundreder gik Vietnam fri for kinesiske angreb og invasioner.

\section{Dien Bien Phus kanoner}

Vietnam og Kina har siden Frankrigs retræte fra Indokina i 1954 haft et broget og komplekst indbyrdes forhold. Ikke mange historieskrivere i Vesten er klar over, at det var kinesiske artillerister, der leverede et vigtigt bidrag til at sikre de nordvietnamesiske soldater, ledet af den legendariske general Vo Nguyen Giap, sejren over franske styrker i det historiske

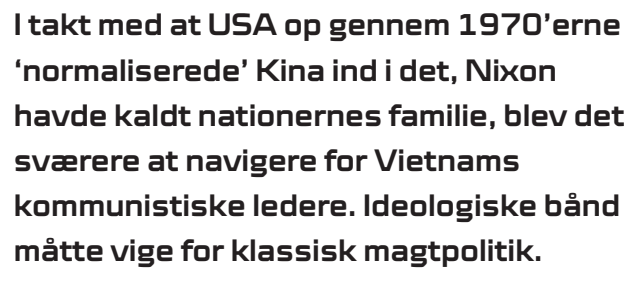


slag ved Dien Bien Phu fra 13. marts til 7. maj 1954 (Kilde: Miles Yaochun Yu: The Lessons of Dien Bien Phu 22.12.2017 på hoover.org/research/ lessons-dien-bien-phu).

I takt med at USA op gennem 1970'erne 'normaliserede' Kina ind i det, Nixon havde kaldt nationernes familie, blev det sværere at navigere for Vietnams kommunistiske ledere. Ideologiske bånd måtte vige for klassisk magtpolitik.

Afviklingen af Kinas isolation begyndte i 1971, da Folkerepublikken Kina overtog Republikken Kinas plads i FN og dermed også Kinas faste plads i sikkerhedsrådet. Et skift, der var tidsmæssigt sammenfaldende med, at Nixon og hans sikkerhedsrådgiver Henry Kissinger efter sidstnævntes hemmelige besøg i Beijing året forinden kunne ankom-

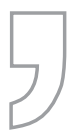
Måske er det realiseringen af en vision, som Richard Nixon formulerede, da han i en pause mellem møderne med de kinesiske ledere Mao Zedong og Zhou Enlai i Beijing i februar 1972 bemærkede følgende til Kissinger: "Hvis Kina nogensinde får en anstændig regering, vil vi ikke kunne slå dem". me til Kina i februar 1972 og indlede dialoger mellem den vestlige supermagt og klodens ældste kontinuerlige civilisation om en ny kurs for verden.

Ingen kunne dengang forudse, at grundlaget for en ny og anderledes indretning af verden blev lagt her.

Kina var i 1972 med Kissingers ord 'et ludfattigt stalinistisk land', der opretholdt en militær konfrontation med USA omkring Taiwan, på den Koreanske Halvø og i det tidligere Fransk Indokina, hvor Kina støttede Nordvietnam og kommunistiske oprørsgrupper i Laos og Cambodja.
Spoler man filmen frem et halvt århundrede i historieskrivningens tidsmaskine, har vi i dag et Kina, der i praksis har forladt Mao-tidens ideologiske galskab, har indført en dynamisk form for statskapitalisme, der i disse år skaber klodens største økonomi, og er ved at give både USA og EU baghjul.

Måske er det realiseringen af en vision, som Richard Nixon formulerede, da han i en pause mellem møderne med de kinesiske ledere Mao Zedong og Zhou Enlai i Beijing i februar 1972 bemærkede følgende til Kissinger: "Hvis Kina nogensinde får en anstændig regering, vil vi ikke kunne slå dem”.

1975 blev et forandringens år for Kina og Sydøstasien. Det proamerikanske styre i Vietnam blev i april

løbet over ende af nordvietnamesiske styrker og året efter formelt genforenet med Nordvietnam under navnet Den Socialistiske Republik Vietnam.

Freden var dog langtfra sikret. Kina og Sovjetunionen befandt sig i en bitter ideologisk strid, der blandt meget andet handlede om, hvem der skulle have den ledende rolle i den såkaldte tredje verden blandt kommunistiske og socialistiske regimer og partisanbevægelser især i Sydøstasien.

Vietnam valgte side i denne konflikt, da Hanoi i november 1978 indgik en 25-årig forsvarsaftale med Mo- 
skva. Denne sikkerhedspagt mistede sin betydning i 1989, da Kina og Sovjetunionen normaliserede relationerne. Siden fulgte opløsningen af Sovjetunionen to år senere. Ligeledes i 1989 trak Vietnam sine styrker ud af Cambodja, som i dag er blevet Kinas mest loyale støtte i den sydøstasiatiske ASEAN-sammenslutning.

\section{Kortvarig krig i 1979}

Vietnams modsætningsforhold til Kina fik et meget brutalt udtryk i en kortvarig grænsekrig i februar-marts 1979. I årets første dage var den kinesiske leder Deng Xiaoping på besøg $\mathrm{i}$ Washington for at markere den fulde normalisering af USA-Kina relationerne. Her skal Deng have bemærket følgende til præsident Jimmy Carter: 'Det lille barn opfører sig uartigt, så det er nødvendigt med en afklapsning'. Kort tid efter bebudede Deng en invasion af Vietnam, som varede en måned og påførte Vietnam store materielle skader og Kina store tab af soldater.

Herefter fulgte et årti med kinesisk støtte til cambodjanske partisaner, inden en kostbar og ambitiøs FN-indsats 1992-94 gav Cambodja en neutral politisk platform og et skrøbeligt demokrati, der i disse år er røget ud på historiens mødding og erstattet af et benhårdt diktatur. Cambodjas stærke mand gennem mere end tre årtier, Hun Sen, blev indsat af vietnameserne i 1979, men er ironisk nok Kinas stærkeste forbundsfælle i det, der i dag ses som Kinas 'baggård'.

Der er løbet meget vand gennem Det Sydkinesiske Hav i de seneste årtier. Vietnam blev i 1995 medlem

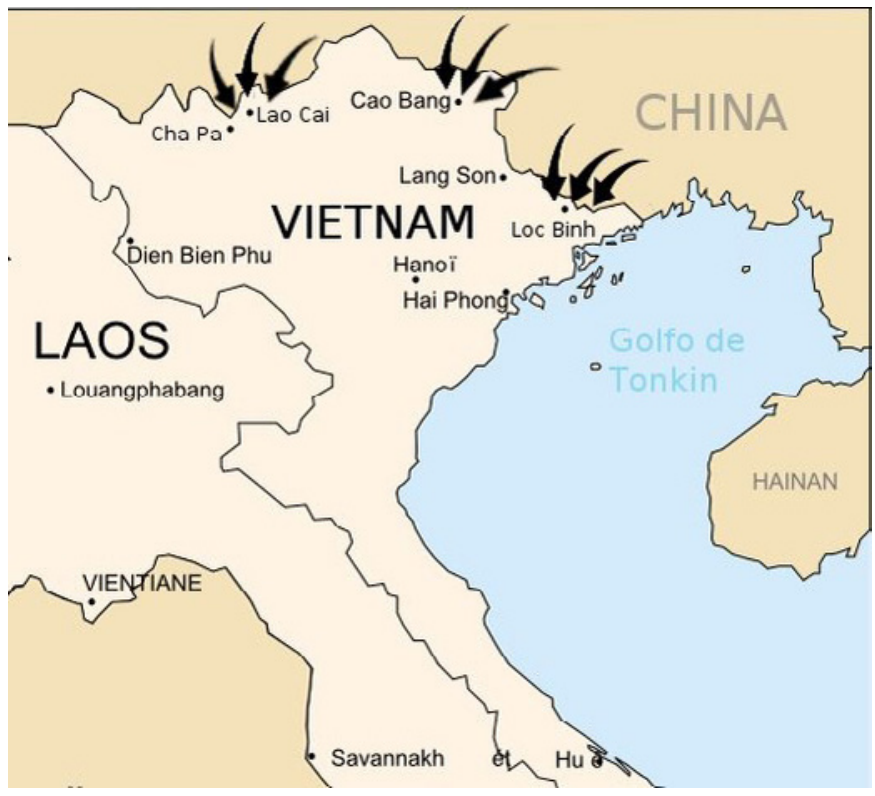

ILL.: Military maps of Vietnam via Wikimedia Commons 
af ASEAN og har efter en reformpolitisk kursændring i 1986 kunnet levere pæne vækstrater, der har forvandlet landet til en økonomisk succeshistorie. De godt 96 millioner vietnamesere, der lever på et areal svarende til lidt større end Norges, er i dag borgere i et land med status af mellemindkomst-samfund.

Både Kina og Vietnam kan i dag siges at repræsentere $\varnothing$ konomiske udviklingsmodeller, som man med et glimt i øjet kan kalde for 'markedsleninistiske'. De forener etpartistyre med en stærkt reguleret kapitalisme med mindelser om den udviklingsstrategi, der blev fulgt af især Taiwan i diktaturtiden under præsident Chiang Kai-shek.

I forhold til udviklingslande, der forsøger sig med vestligt inspirerede demokratiske systemer, har regeringerne i Hanoi og Beijing gjort markante fremskridt i bekæmpelsen af fattigdom.

Dermed har begge etpartistyrer fundet solide argumenter for ikke at indføre systemer, der bygger på principperne om en mand, en stemme; mindst to partier; forfatningssikrede frihedsrettigheder og dertil hørende uafhængige medier; civilsamfund og domstole. For østasiatiske udviklingsstater er dramatisk bedre til at levere velstand end stater og samfund $i$ både det øvrige Asien, Mellemøsten, Afrika og Latinamerika, der forsøger sig med den vestlige demokratimodel.

Men hvor koldkrigslogikken og de ideologiske modsætninger er lagt på hylden, er traditionel geopolitik og dens faste ledsagere - økonomiske og territoriale interessesfærer - rykket ind. Spørgsmålet for Vietnams ledere er, hvorledes de bedst navigerer over for en nordlig nabo, der for længst er blevet en økonomisk supermagt.

Kort sagt: Er Kinas økonomiske mirakel ensbetydende med Vietnams politiske mareridt?

Vietnam og Kina hører kulturelt til i den kungfutsiansk-buddhistiske kulturkreds og var i anden halvdel af det 20. århundrede ledet af ortodokse marxistisk-leninistiske partier, hvis ideologiske orientering langtfra er afskaffet, men er blevet blandet op med nationalisme, pragmatisme og meritokrati.

Denne interessante hybrid har gjort Kina til klodens største handelsnation og i løbet af få år en økonomi, der ikke kun matcher, men overhaler USA.

Denne proces bliver ikke bremset af de nye politiske vinde i USA, snarere det modsatte. Den amerikanske præsident Donald Trump hævder at ville gøre Amerika stort igen, men inden det kommer så vidt, når hans impulsive og inkonsistente regeringsførelse at bidrage til at gøre Kina stort igen.

\section{Trump disrupter Østasien}

Disruption kan vise sig at være for mild en betegnelse for den tilstand, som amerikansk udenrigspolitik ramte Øst- og Sydøstasien med i tiden efter valget af Donald Trump som præsident i november 2016.

Chokbølgerne skyllede gennem verdensdelen fra Tokyo til Hanoi, da USA's nyvalgte præsident valgte at skrotte partnerskabsaftalen TPP, Trans-Pacific Partnership, der havde været præsident Barack Obamas vision for et revitaliseret amerikanskledet partnerskab i Østasien. 
Obama ønskede at tilbyde en ramme for de lande i Asien, som ikke mente at ville høre

hjemme i den nye Beijing-ledede orden i Asien. Altså den orden, som er ved at tegne sig med afsæt i Bei-

jings såkaldte Belt and Road Initiative, der sine steder også kaldes One Belt, One Road (OBOR), historiens største infrastrukturprogram.

I månederne op til valget af Trump var der udbredte formodninger om, at et USA under en præsident Hillary Clinton ville have mobiliseret Washingtons traditionelle allierede i en moderne udgave af den inddæmningspolitik, som var gældende under den kolde krig. At USA med sin 7. flåde, flybaser i Japan og Sydkorea og et militært personel på lidt over 80.000 i disse to lande kunne levere den nødvendige sikkerhedspolitiske ramme for en målsætning om at bremse for yderligere kinesisk økonomisk og militær ekspansion.

Sådan kom det ikke til at gå. Ganske vist vandt USA's ældste alliancepartner i regionen, Filippinerne, i juli samme år den sag, som regeringen i Manila havde rejst ved det Internationale Havretstribunal i Haag, og som afgjorde, at de kinesiske landfyldninger i Det Sydkinesiske Hav er i strid med FN's Havretskonvention af 1982, Unclos.

Kina ignorerede kendelsen og tilbød den filippinske regering et økonomisk partnerskab. Dermed var en afgørende magtforskydning i Sydøstasien sat $i$ gang.
Ironisk nok er Kina underskriver af havretskonventionen, mens USA ikke 
siden 1945, og det er her, at disse små og spredte klynger af øer og klipperev får større betydning. Men USA kan næppe agere som den 'politibetjent', der håndhæver havretskonventionen, når Washington ikke er medunderskriver.

I stedet har Trump overtaget forgængeren Obamas politik med de såkaldte FONOP-sejladser. FONOP står for Freedom of Navigation Operations, der indebærer, at USA garanterer fri ret til gennemsejling uden at tage stilling til stridighederne om grænsedragningen.

Problemet med FONOPs er, at de ikke har standset de kinesiske landfyldninger, heller ikke efter at satellitfotos fra foråret 2018 viser, at Kina er ved at opstille missilramper på nogle af områderne. Så sent som i maj i år har regeringen i Hanoi protesteret skarpt mod den kinesiske opstilling af missilramper.

Af alle lande i Sydøstasien er det Vietnam, der ser med størst bekymring på den kinesiske ekspansion. Det skyl- flere lejligheder taget skridt til at trodse kineserne. Regeringen i Hanoi har tilladt udenlandske energiselskaber i farvande, som Kina gør krav på, og har forsøgt sig med opbygning af faciliteter $i$ havet om end $i$ et langt mere beskedent omfang end Kina.

Det vietnamesiske initiativ på dette område er indtil videre endt med en alvorlig ydmygelse. Således blev det statslige spanske olieselskab Repsol tvunget til at trække sig ud af Det Sydkinesiske Hav efter kinesisk pres. Repsol havde angiveligt investeret omkring 300 mio. dollar i olie- og gasefterforskning og har nu anmeldt erstatningskrav over for Vietnam.

\section{Tættere på USA}

Vietnam har af selvindlysende grunde opbygget tættere politiske og strategiske relationer med sin gamle krigsmodstander USA.

En partnerskabsaftale indgået under præsident Obama betyder, at USA har ophævet et gammelt forbud om våbeneksport til Hanoi. Som en tilkendegivelse af, at vietnameserne gerne spiller 'USA-kortet' i det regionale magtspil, besøgte Trumps

des et årtusindgammelt modsætningsforhold, som aktuelt giver sig udtryk i de to landes territorielle krav i det farvand, som Vietnam kalder 'Østhavet', mens Kina og alle andre bruger betegnelsen Det Sydkinesiske Hav.

Hvor de øvrige sydøstasiatiske lande har lurepasset i diskussionen om Kinas ambitioner, har Vietnam ved forsvarsminister James Mattis Vietnam i januar i år.

Men der er også tegn på, at vietnameserne erkender begrænsningerne $i$ at læne sig for meget op ad Trumps udenrigspolitiske orientering. For hvordan forholder man sig lige til en amerikansk præsident, der kalder sin kinesiske kollega Xi Jinping for en 'ven'? 
Den økonomiske partnerskabsaftale, TPP, som præsident Trump trak USA ud af, ville have givet Vietnams vækst og udvikling et kolossalt løft. Da Trump i november i fjor holdt en tale på APEC-topmødet (Asia Pacific Economic Cooperation) i den vietnamesiske kystby Da Nang, blev værterne næppe fornøjede over præsidentens protektionistiske budskaber.

Vietnam må derfor erkende begrænsningerne i relationerne til USA og søge andre partnere. Hanoi og Tokyo indgik i 2014 en strategisk partnerskabsaftale, der betyder, at Japan nu leverer patruljebåde og observationssatellitter til Vietnam. USA har leveret flere patruljefartøjer i de senere år. Den vietnamesiske regering har iværksat et militært moderniseringsprogram, der er på vej til at skabe den muligvis største flåde af undervandsbåde i Sydøstasien.

Men der er begrænsninger i, hvor langt Vietnam kan gå i at risikere vrede fra den store nabo i nord.

\section{Kineserne i Da Nang}

Et anderledes magthierarki er under opbygning i Øst- og Sydøstasien.

Da franskmændene forlod Indokina efter nederlaget ved Dien Bien Phu i 1954, udgjorde den amerikanske andel af verdensøkonomien 50 pct. Andelen var faldet til 25 pct. ved den kolde krigs afslutning. Her i 2018 er den under 20 pct., og ved starten af næste årti er den med stor sandsynlighed faldet til en halv snes pct. Læg hertil den forvirring, som Trump med sin ledelsesstil bidrager til blandt både allierede og potentielle og reelle rivaler.

Den vietnamesiske kystby Da Nang blev i marts 1965 den lokalitet, hvor de første ca. 2.000 amerikanske soldater gik i land som et led i Lyndon Johnsons optrappede krigsførelse. Landgangen blev begrundet med, at den luftbase, der lå i nærheden af byen, skulle beskyttes. Få år senere havde USA en halv million mand i Sydvietnam og udsigt til et forsmædeligt nederlag. Lufthavnen i Da Nang betjener i dag overvejende turister fra Kina. Lidt over 10 mio. turister kommer til Vietnam hvert år, en fjerdedel af dem er kinesiske statsborgere.

I 2014 trak kinesiske skibe en boreplatform ud til et punkt syd for Paracel-øerne i Det Sydkinesiske Hav kun $220 \mathrm{~km}$ fra den vietnamesiske kyst og dermed inden for Vietnams økonomiske zone. Vietnamesiske fiskerifartøjer sejlede ud for at protestere, men flere af dem blev påsejlet, og et enkelt blev sænket. Begivenheden udløste protestdemonstrationer på virksomheder i Vietnam, hvor der også arbejdede kinesere.

Flere end 400 kinesisk-ejede virksomheder blev helt eller delvist ødelagt af rasende demonstranter, der med stor sandsynlighed blev tilskyndet af myndighederne.

Herefter udstedte de kinesiske myndigheder en advarsel til sine borgere om ikke at rejse til Vietnam, hvorefter turistindustrien i Da Nang fik alvorlige lommesmerter. Vietnam har en god sag mod Kina, men den er ikke af den slags, der gavner beskæftigelse og betalingsbalance.

Vietnam er godt på vej til at blive endnu en fjernøstlig tigerøkonomi, men landet må i en stærkt foranderlig verden navigere i et uroligt farvand. Den kulturelle patriark i nord kaster lange skygger ind over opkomlingen. 